\title{
Mild Hypoxia Promotes Survival and Proliferation of SOD2-Deficient Astrocytes via c-Myc Activation
}

\author{
Jing Liu, Purnima Narasimhan, Yong-Sun Lee, Yun Seon Song, Hidenori Endo, Fengshan Yu, and Pak H. Chan \\ Department of Neurosurgery, Department of Neurology and Neurological Sciences, and Program in Neurosciences, Stanford University School of Medicine, \\ Stanford, California 94305-5487
}

\begin{abstract}
Mouse astrocytes deficient in the mitochondrial form of manganese superoxide dismutase (SOD2) do not survive in culture under atmospheric air with $20 \%$ oxygen $\left(\mathrm{O}_{2}\right)$, which is a common condition for cell cultures. Seeding the cells and maintaining them under mild hypoxic conditions $\left(5 \mathrm{~F}_{2}\right)$ circumvents this problem and allows the cells to grow and become confluent. Previous studies from our laboratory showed that this adaptation of the cells was not attributable to compensation by other enzymes of the antioxidant defense system. We hypothesized that transcriptional activity and upregulation of genes other than those with an antioxidant function are involved. Our present study shows that c-Myc was significantly induced and that it inhibited p21 and induced proteins such as cyclindependent kinases, cyclin D, and cyclin E, which are involved in the cell cycle process, along with phosphorylation of the retinoblastoma protein and Cdc2 (cell division cycle 2). These mechanisms contribute to cell proliferation. Small interfering RNA of c-Myc, however, blocked proliferation of SOD2 homozygous (SOD2-I-) astrocytes under mild hypoxia consisting of $5 \% \mathrm{O}_{2}$, whereas it did not affect the growth of wild-type astrocytes. Our results indicate that c-Myc plays a critical role in hypoxia-induced proliferation and survival of SOD2 $-I-$ astrocytes by overcoming injury caused by oxidative stress.
\end{abstract}

Key words: oxidative stress; mitochondria; manganese superoxide dismutase; hypoxia; c-Myc; cyclin-dependent kinases

\section{Introduction}

Superoxide radicals, along with other reactive oxygen species (ROS), are toxic to cells when generated in excess and can cause severe damage to DNA, proteins, and lipids, leading to cell death (Chan, 1996). They also affect the various molecular components of cells, including mitochondria. Mitochondrial dysfunction results in necrotic cell death via loss of ATP production. Several cellular and biochemical signaling pathways in mitochondria also activate the caspases and are thus involved in apoptosis (Chan, 2005). These processes are exacerbated in mice that are deficient in manganese superoxide dismutase (SOD2), suggesting that oxidative stress precedes mitochondrial-derived apoptosis. Previous work from our laboratory showed that mouse astrocytes completely deficient in the mitochondrial form of SOD2 did not grow and subsequently died in $20 \%$ atmospheric oxygen $\left(\mathrm{O}_{2}\right)$. Seeding the cells under $5 \% \mathrm{O}_{2}$ circumvented this problem and allowed the cells to grow and become confluent (Copin et al., $2001)$. The factors induced by mild hypoxia $\left(5 \% \mathrm{O}_{2}\right)$ that overcome SOD2 deficiency and contribute to proliferation of homozygous SOD2-1- astrocytes are important and can explain the adaptive response of these astrocytes.

One of the key genes involved in hypoxia is the transcription

Received 0ct. 3, 2005; revised March 16, 2006; accepted March 16, 2006

This work was supported by National Institutes of Health Grants P50 NS14543, R01 NS25372, R01 NS36147, and R01 NS38653 and an American Heart Association Bugher Foundation Award.

Correspondence should be addressed to Dr. Pak H. Chan, Neurosurgical Laboratories, Stanford University, 1201 Welch Road, MSLS \#P304, Stanford, CA 94305-5487. E-mail: phchan@stanford.edu.

D01:10.1523/JNEUROSCI.0382-06.2006

Copyright $\odot 2006$ Society for Neuroscience $\quad$ 0270-6474/06/264329-09\$15.00/0 factor hypoxia-inducible factor-1 (HIF-1) (Semenza, 1999). Carmeliet et al. (1998) showed that induction of HIF-1 $\alpha$ activation prevented $\mathrm{G}_{1} / \mathrm{S}$ transition, suggesting that HIF- $1 \alpha$ inhibits cell growth. Current theory on hypoxic signaling relies on ROS as mediators of hypoxia-induced gene transcription (Semenza, 1999; Liu et al., 2005). In addition to HIF- $1 \alpha$, c-Myc is widely known as a crucial regulator of proliferation of normal and neoplastic cells and is induced by ROS (Simon et al., 1998). Most importantly, HIF- $1 \alpha$ functionally antagonizes c-Myc (Koshiji et al., 2004). Our study examined the roles that c-Myc and HIF- $1 \alpha$ may play in the survival and proliferation of SOD2-/astrocytes.

Cells that proliferate go through a cycle consisting of the $G_{1}, S$, $\mathrm{G}_{2}$, and $\mathrm{M}$ phases. Cell proliferation is primarily regulated at the $\mathrm{G}_{1}$ phase of the cycle (Liu et al., 1998). The retinoblastoma protein $(\mathrm{Rb})$ is essential for the $\mathrm{G}_{1} / \mathrm{S}$ checkpoint, and its phosphorylation by the cyclin $\mathrm{D}$ and $\mathrm{E} /$ cyclin-dependent kinase (CDK) complexes nullifies growth-suppressive activity. Cyclin/CDK complex activity is modulated by binding to CDK inhibitors such as p27 and p21, preventing them from inhibiting the function of cyclin E/CDK2 and allowing the cells to enter S phase.

Growing evidence indicates that hypoxia alters cellular proliferation by programmed cell death and by cell cycle arrest (Shimizu et al., 1995). Most nontransformed hypoxic cells remain viable but are arrested in $G_{1}$ and do not proliferate (Graeber et al., 1996). Previous studies indicate that hypoxia-induced cell cycle arrest is accompanied by decreased activity of certain CDK complexes and hypophosphorylation of Rb, leading to inhibition of cell cycle progression (Gardner et al., 2001). In contrast, SOD2 $-/-$ cells have been shown to proliferate under $5 \% \mathrm{O}_{2}$ 
hypoxia. In this study, we examined the role of cell cycle proteins in the survival of cultured astrocytes derived from SOD2 knockout mice under $5 \% \mathrm{O}_{2}$ hypoxia where, instead of cell cycle arrest, cell proliferation occurs.

\section{Materials and Methods}

SOD2-deficient mice. The animals used in this study were mutated by a method of homologous recombination and subsequent inactivation of the SOD2 gene. These CD-1/SV129 mice were generated from our laboratory and were extensively bred on a CD-1 background for $>10$ generations (Li et al., 1995). Homozygous SOD2 knock-out animals died at $\sim 10 \mathrm{~d}$ after birth because of a heart abnormality. These SOD2 - / - mice were produced by crossing two heterozygous SOD2 - /+ mice. Immediately after birth, the animals were typed by PCR amplification of mutant and normal fragments of the SOD2 gene from tail DNA obtained by proteinase K digestion as described previously (Li et al., 1995).

Primary astrocyte culture. Astrocytes were cultured as described by Chan et al. (1988) with minor modifications. Briefly, cortical tissue of newborn mice was dissociated by $0.25 \%$ trypsin and passed sequentially through $80 \mu \mathrm{m}$ and then $10 \mu \mathrm{m}$ filtration meshes. Cell suspensions in minimum essential medium (MEM; Invitrogen, Grand Island, NY) supplemented with $20 \%$ fetal bovine serum (Gemini Bio-Products, Calabasas, CA) were plated into 24 multiwell plates or 35 or $60 \mathrm{~mm}$ dishes (Falcon; BD Biosciences, Franklin Lakes, NJ) at a dilution of one brain per $48 \mathrm{~cm}^{2}$ and incubated at $37^{\circ} \mathrm{C}$ under $5 \% \mathrm{CO}_{2}$-air atmosphere in a water-jacketed incubator (Forma Scientific, Marietta, OH) or under 5\% $\mathrm{O}_{2}-5 \% \mathrm{CO}_{2}-90 \% \mathrm{~N}_{2}$ in a gas-tight humidified chamber (modular incubator chamber; Billups-Rothenberg, Del Mar, CA). After $4 \mathrm{~d}$, the culture medium was replaced with fresh MEM containing $10 \%$ fetal bovine serum, and the astrocytes were fed twice per week. c-Myc small-interfering RNA (siRNA) was administered when cells reached $50 \%$ confluence.

Cell death assay. The 2,3'-azino-bis(ethylbenzothiazoline-6-sulfonic acid) (ABTS)/enzyme-linked immunosorbent assay method used for quantification of cell death is a fast, reliable, and objective procedure (Brooke et al., 1999). Cells were fixed by adding cold methanol. After blocking with 5\% dry milk in PBS overnight, glial fibrillary acidic protein antibody was added at a 1:1000 dilution for $30 \mathrm{~min}$. The cells were then washed and incubated in a secondary antibody for $30 \mathrm{~min}$, followed by incubation with the $\mathrm{ABC}$ reagent (ABC kit; Vector Laboratories, Burlingame, CA) for $30 \mathrm{~min}$, and then incubated in ABTS for 20-30 min. Colorimetric readings were taken at $405 \mathrm{~nm}$ using an ELISA plate reader.

In situ detection of superoxide anion production. The early production of superoxide anions after hypoxia was investigated using hydroethidine (HEt) as in a previously described method (Bindokas et al., 1996). HEt is selectively oxidized to ethidium by superoxide anions, but not by other ROS such as hydrogen peroxide, hydroxyl radical, or peroxynitrite. HEt solution ( $1 \mathrm{mg} / \mathrm{ml}$ in MEM) was administered directly to the control group (cells that were at $20 \% \mathrm{O}_{2}$ ) and to cells immediately after they were taken out of the $5 \% \mathrm{O}_{2}$ hypoxic chamber. The cells were then incubated for $5 \mathrm{~min}$ in the solution. They were washed three times in PBS, and after fixation with $4 \%$ paraformaldehyde for $10 \mathrm{~min}$, the slides were covered with VECTASHIELD mounting medium with 4',6-diamidino-2phenylindole (DAPI) (Vector Laboratories). These sections were observed under a fluorescent microscope at an excitation of $355 \mathrm{~nm}$ and an emission of $>415 \mathrm{~nm}$ for HEt.

Western blot analysis. To obtain enough cells to represent "normal conditions" for Western blotting, we first cultured SOD2 $-/-$ mouse astrocytes in $5 \% \mathrm{O}_{2}$ hypoxia for $5 \mathrm{~d}$ (when the cells were not confluent) and then continued with normal culture conditions for $3 \mathrm{~d}$. The cells were rinsed with cold PBS, lysed for $15 \mathrm{~min}$ on ice in lysis buffer, sonicated, and centrifuged at $4^{\circ} \mathrm{C}$. Supernatants were collected, and an equal volume $2 \times$ SDS sample buffer (Invitrogen, Carlsbad, CA) was added. Protein samples were boiled for $5 \mathrm{~min}$ and separated on $4-12 \%$ or $10-$ $20 \%$ Tris-glycine Novex gels (Invitrogen) and transferred to polyvinylidene difluoride membranes and then blocked with $5 \%$ milk in PBSTween 20, followed by incubation with the respective primary antibody overnight at $4^{\circ} \mathrm{C}$. The membranes were then washed and incubated in secondary antibody for $1 \mathrm{~h}$ and washed with PBS-Tween. The bound antibody was visualized using an ECL-Plus kit (Amersham Biosciences, Piscataway, NJ). The bands were scanned using a densitometer (GS-700; Bio-Rad, Hercules, CA), and quantification was performed using MultiAnalyst 1.0.2 software (Bio-Rad).

Coimmunoprecipitation. Immunoprecipitation was performed as described previously (Saito et al., 2004). Three hundred micrograms of protein from the cytosolic fraction were used for coimmunoprecipitation. The protein sample was incubated with a $50 \%$ slurry of protein $\mathrm{G}$-Sepharose (Amersham Biosciences) for $1 \mathrm{~h}$ at $4^{\circ} \mathrm{C}$, and this mixed sample was centrifuged at $12,000 \times g$ for $1 \mathrm{~min}$. The supernatant was incubated with $2 \mu \mathrm{g}$ of monoclonal mouse anti-CDK4 antibody (Cell Signaling Technology, Beverly, MA) and $15 \mu$ l of protein G-Sepharose (50\% slurry) for $1 \mathrm{~h}$ at $4^{\circ} \mathrm{C}$. The negative control was prepared with protein G-Sepharose without an antibody. The $14,000 \times g$ pellets were washed three times and used as the samples bound to each antibody. After adding the same volume of Tris-glycine SDS sample buffer (Invitrogen) to the samples, they were boiled to remove the Sepharose beads. After centrifugation at $14,000 \times g$ for $1 \mathrm{~min}$, the supernatant was immunoblotted with a 1:600 dilution of anti-cyclin D antibody (Cell Signaling Technology), as described for the Western blot method.

Immunocytochemistry. Astrocytes were cultured on glass coverslips. The cells were fixed with $4 \%$ paraformaldehyde. They were then incubated with blocking solution followed by incubation overnight with an anti-c-Myc antibody at a dilution of 1:100. Secondary goat anti-rabbit IgG antibody conjugated with Texas Red (Jackson ImmunoResearch, West Grove, PA) was added at a dilution of 1:200. The cells were then mounted with VECTASHIELD medium with DAPI (Vector Laboratories). Fluorescence of Texas Red was observed at excitation of $510 \mathrm{~nm}$ and emission of $>580 \mathrm{~nm}$. Fluorescence of DAPI was observed at excitation of $360 \mathrm{~nm}$ and emission of $>460 \mathrm{~nm}$ using a laser confocal microscope (LSM 510; Zeiss, Thornwood, NY).

Transfection of $c-M y c$ siRNA in astrocytes. c-Myc or nontarget mutant (control) siRNA diluted in OPTI-MEM I was added to diluted siPORT Lipid (Ambion, Austin, TX) and incubated at room temperature for 20 min. Cells were washed with OPTI-MEM I, and a transfection agent/ siRNA complex with a final concentration of $100 \mathrm{~nm}$ was added dropwise and incubated for $4 \mathrm{~h}$. Fresh growth medium was added to each well and incubated for $48 \mathrm{~h}$. Transfection efficiencies were determined by immunofluorescence of targeted cells and were in the range of $80 \%$. Specific silencing of the targeted gene was confirmed by Western blot analysis of the knockdown protein c-Myc.

Treatment of astrocytes with antisense $c-M y c$. The antisense oligonucleotide for c-Myc was 5'-CACGTTGAGGGGCATCGTCGC-3' (Devi et al., 2005). The sense oligomer 5' -GCGACGATGCCCCTCAACGTG-3' served as a control. A 50 or $100 \mathrm{~nm}$ concentration of the oligomers was added directly to the cells and placed under $5 \% \mathrm{O}_{2}$. After treatment, cell death was assessed using a lactate dehydrogenase assay. Total RNA was prepared from the astrocytes using a Micro-to-Midi Total RNA Purification System (Invitrogen). For reverse transcriptase (RT)-PCR analysis, SuperScript One-Step RT-PCR kit with Platinum Taq (Invitrogen) was used with a total volume of $50 \mu \mathrm{l}$. Specific primer pairs for c-Myc were used as follows (Forte et al., 2005): forward, $5^{\prime}$-CTTCCCCTACCCGCTCAACGAC-3'; reverse, $5^{\prime}$-CACATCAATTTCTTCCTCATCA-3'. As a control, $\beta$-actin was amplified with the following primers: forward, $5^{\prime}$ ACCCACACTGTGCCCATCTAA-3'; reverse, $5^{\prime}$-GCCACAGGATTCCATTACCCAA-3'. The mixtures were subjected to RT-PCR on a thermal cycler (Mastercycler Gradient; Eppendorf, Westbury, NY). RT-PCR conditions for c-Myc were $45^{\circ} \mathrm{C}$ for $30 \mathrm{~min}, 94^{\circ} \mathrm{C}$ for $2 \mathrm{~min}, 30$ cycles of $94^{\circ} \mathrm{C}$ for $15 \mathrm{~s}, 56^{\circ} \mathrm{C}$ for $30 \mathrm{~s}, 72^{\circ} \mathrm{C}$ for $15 \mathrm{~s}$, and then $72^{\circ} \mathrm{C}$ for $5 \mathrm{~min}$. RT-PCR products were electrophoresed on $1 \%$ agarose gels and stained with ethidium bromide. After electrophoresis, the gels were recorded with a gel documentation system (GS700; Bio-Rad).

Quantification and statistical analysis. All data were obtained from three to five independent experiments and are expressed as mean \pm SD, and for each experiment multiple measurements were made on three to six different dishes or wells. Comparisons among multiple groups were performed using a one-way ANOVA (Fisher's protected least significant difference test) with appropriate post hoc tests (StatView, version 5.01; SAS Institute, Cary, NC), whereas comparisons between two groups were 


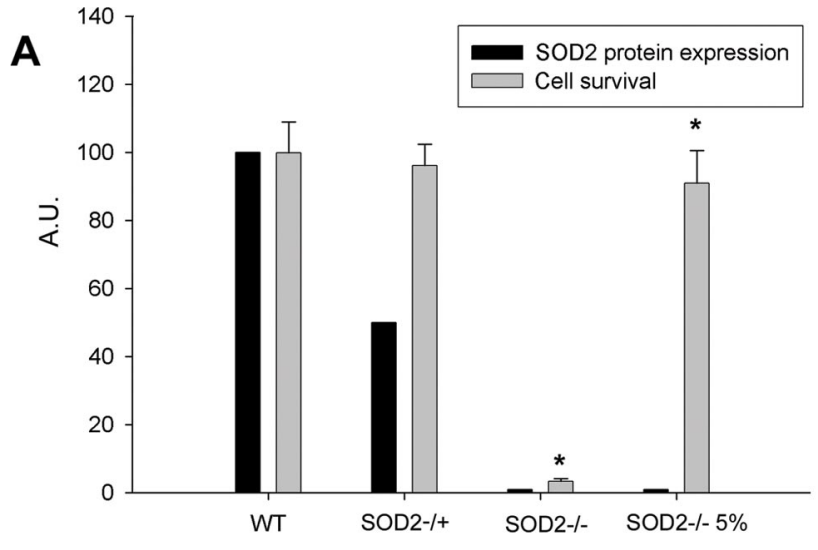

B
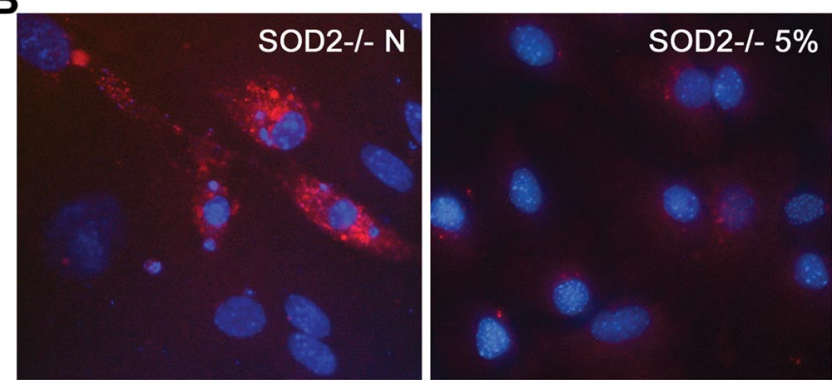

Figure 1. Five percent $\mathrm{O}_{2}$ greatly improved survival of $\mathrm{SOD2}-/-$ astrocytes under normal culture conditions. $A$, SOD2 protein expression levels and cell viability measured by ABTS in wild-type (WT), SOD2 - / , and SOD2 - / - astrocytes cultured under normal conditions and SOD2 $-1-$ astrocytes cultured under $5 \% \mathrm{O}_{2}$ hypoxia (SOD2 $-/-5 \%$ ). The levels of SOD2 expression were significantly different among these three groups $(p<0.01)$. Cell survival among the three groups was also different and was significant between the SOD2 $-1-5 \%$ astrocytes and the WT and SOD2 $-1+$ astrocytes $\left({ }^{*} p<0.01\right)$. The SOD2 $-1-5 \%$ cells showed a significant improvement in survival ( $\left.{ }^{*} p<0.01 ; n=3-5\right)$. A.U., Arbitrary units. $\boldsymbol{B}$, ROS production shown by HEt (red) and DAPI (blue) staining of SOD2 - / - astrocyte culture under "normal" conditions (SOD2 - / - N) and 5\% $0_{2}$ hypoxia (SOD2 - / - 5\%). HEt staining was observed as punctate particles in the cells grown under normal conditions. Magnification is $400 \times$. Error bars represent SEM.

achieved using Student's $t$ test. $p \leq 0.05$ was considered statistically significant.

\section{Results}

Five percent oxygen greatly improved the survival of SOD2 $-/-$ astrocytes under normal culture conditions

Cell death was measured using a modification of an immunohistochemical staining method (ABTS) with an astrocyte-specific antibody against glial fibrillary acidic protein, which allows for quantification of astrocytes using an enzyme-linked immunosorbent assay plate reader. Under standard culture conditions, heterozygous SOD2-/+ and wild-type astrocytes had the same survivability, whereas homozygous SOD2-/- cells did not grow. Under $5 \% \mathrm{O}_{2}$ hypoxic conditions, SOD2-/- astrocytes dramatically proliferated and reached confluence similar to normal astrocytes (Fig. 1A). The level of SOD2 was examined in the wildtype, SOD2 $-/+$, and SOD2 $-/-$ astrocytes. There was no SOD2 expression in the SOD2-1- astrocytes, whereas 50\% expression was observed in the SOD2 $-1+$ compared with the wild-type astrocytes (Fig. $1 \mathrm{~A}$ ). Under $5 \% \mathrm{O}_{2}$ hypoxia, ROS production as shown by HEt staining was significantly lower in the SOD2-/astrocytes compared with normal culture conditions in atmospheric $20 \% \mathrm{O}_{2}$ (Fig. $1 \mathrm{~B}$ ), whereas there was no significant difference in the wild-type astrocytes under such conditions (supplemental Fig. 1, available at www.jneurosci.org as supplemental material). HEt staining was punctate, which supports our previous report (Sugawara et al., 2002) describing double staining of ethidium and the mitochondrial marker MitoTracker, which demonstrated that many of the punctate superoxide signals were colocalized with mitochondria, confirming mitochondria as a major source of superoxide production.

\section{Improvement in survival with $5 \% \mathrm{O}_{2}$ hypoxia is not through expression of $\mathrm{Bcl}-2$-family proteins}

Bcl-2 is known to protect against enhanced oxidative stress caused by various ROS-inducing agents. To investigate whether they had a role in rescuing the SOD2-/- astrocytes, we examined several members of the Bcl-2 family of proteins. Western blot analysis demonstrated a basal level in $\mathrm{Bcl}-2$ expression in the wild-type astrocytes. Five percent $\mathrm{O}_{2}$ hypoxia did not have any influence on this expression. However, there was an increase in Bcl-2 in the SOD2-/+ astrocytes compared with the wild-type astrocytes under both normal conditions and 5\% $\mathrm{O}_{2}$ hypoxia (data not shown). In the SOD2-/- astrocytes, expression of the Bcl-2 protein significantly increased compared with both the wild-type and SOD2-1+ astrocytes, whereas under 5\% $\mathrm{O}_{2}$ hypoxia, a decrease in the expression of Bcl-2 in the SOD2- $/-$ astrocytes was observed (Fig. 2). Bcl- $\mathrm{X}_{\mathrm{L}}$ showed a similar pattern of expression, with a decrease in SOD2 - / - astrocytes under $5 \% \mathrm{O}_{2}$ hypoxia (Fig. 2). Expression of Bad, a proapoptotic protein, also decreased in the SOD2-/- astrocytes under $5 \% \mathrm{O}_{2}$ hypoxia. There was no difference in Bax protein expression between normal conditions and $5 \% \mathrm{O}_{2}$ hypoxia (Fig. 2). In summary, the Bcl-2 family of proteins did not play a significant role in promoting survival and growth of the SOD2- - astrocytes under $5 \% \mathrm{O}_{2}$ hypoxia (Fig. 2).

\section{c-Myc rather than HIF-1 $\alpha$ was induced in SOD2 knock-out astrocytes under $5 \% \mathrm{O}_{2}$ hypoxia}

HIF- $1 \alpha$ is known to be induced by hypoxia. HIF- $1 \alpha$ protein expression was not induced in either the wild-type or the SOD2 knock-out astrocytes under normal conditions or $5 \% \mathrm{O}_{2}$ hypoxia (Fig. 3A). In cells subjected to anoxic conditions $\left(0 \% \mathrm{O}_{2}\right)$, HIF- $1 \alpha$ induction was observed (positive control in Fig. $3 A$ ). Along with HIF-1 $\alpha$, c-Myc is widely known as a crucial regulator of proliferation of normal and neoplastic cells and is induced by ROS (Simon et al., 1998). There was no difference in c-Myc expression in the wild-type astrocytes under normal conditions or $5 \% \mathrm{O}_{2}$ hypoxia. In the SOD2-/+ astrocytes, c-Myc expression was lower than in the wild-type astrocytes under normal conditions but was induced under $5 \% \mathrm{O}_{2}$ hypoxia. There was no c-Myc expression in the SOD2 $-/-$ astrocytes under normal conditions, but it was significantly induced with $5 \% \mathrm{O}_{2}$ hypoxia (Fig. $3 \mathrm{~B}, \mathrm{C}$ ), and $\mathrm{c}-\mathrm{Myc}$ staining was strong in cells that underwent mitosis (Fig. 3D). Thus, a critical difference in c-Myc expression was seen between wild-type astrocytes and SOD2-deficient astrocytes.

\section{Five percent $\mathrm{O}_{2}$ hypoxia induced SOD2-/- astrocytes to pass} through a cell cycle checkpoint

Because c-Myc expression was upregulated in SOD2-/- astrocytes under mild hypoxia, the downstream proteins under c-Myc that are involved in the cell cycle pathway were examined. Under $5 \% \mathrm{O}_{2}$ hypoxia, there was significant phosphorylation of $\mathrm{Rb}$ at Ser ${ }^{807 / 811}$ in the SOD2-/- cells compared with the cells grown under normal culture conditions. This upregulation in phosphorylation of $\mathrm{Rb}$ was not seen in the wild-type astrocytes. Expression of cyclin D, CDK4, CDK6, cyclin E, and CDK2 increased in the SOD $2-/-$ astrocytes with $5 \% \mathrm{O}_{2}$ hypoxia as demonstrated 
A

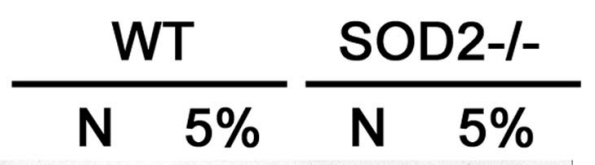

$\mathrm{Bcl}-2$
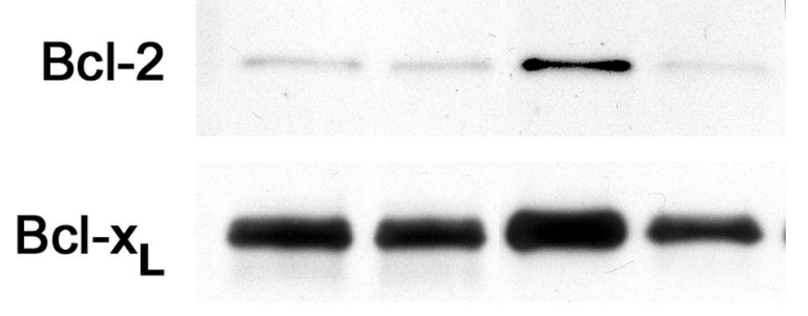

Bad

Bax

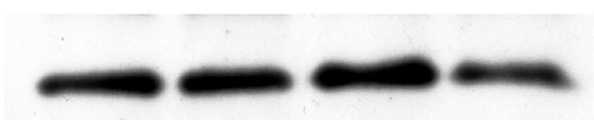

$\beta$-Actin

B

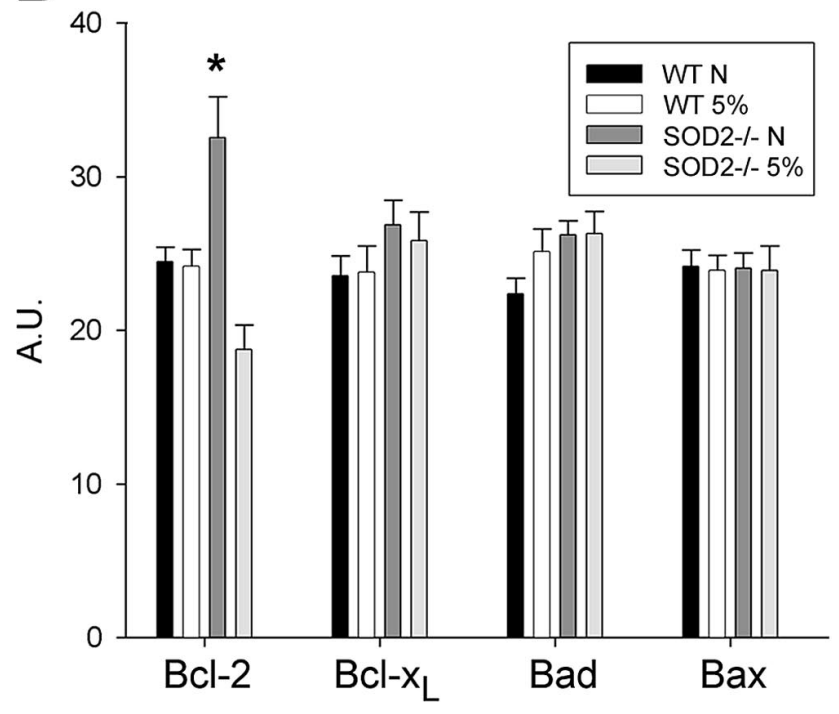

Figure 2. $\mathrm{BCl}-2$ family of proteins does not play a significant role in $\mathrm{SOD} 2-/-$ survivability. $\boldsymbol{A}$, Western blot analysis of Bcl family members BCl-2, BCl-X $\mathrm{L}_{\mathrm{L}}$ Bad, and Bax in wild-type (WT) and SOD2 - I- (SOD2 - / - ) mouse astrocyte cultures under normal conditions (N) and $5 \% 0_{2}$ hypoxia (5\%). No significant difference was observed in the wild-type astrocytes between the two conditions. In the SOD2 - / - astrocytes, there was an increase in $\mathrm{BCl}-2, \mathrm{BCl}-\mathrm{X}_{\mathrm{L}}$, and Bad under normal conditions compared with $5 \% \mathrm{O}_{2}$ hypoxia and compared with the wild-type astrocytes, whereas there was no change in Bax. $\beta$-Actin was used as an internal control. $\boldsymbol{B}$, Densitometric analysis showed a significant difference only in $\mathrm{BCl}-2$ between the SOD2 - / - and wild-type astrocytes under normal conditions ( ${ }^{*} p<0.05 ; n=3$ independent experiments).

by Western blot analysis. In the wild-type astrocytes, there was no significant difference in phosphorylated cell division cycle 2 (Cdc2) expression between normal conditions and 5\% $\mathrm{O}_{2}$ hypoxia, whereas, in the SOD2-/- astrocytes, Cdc2 phosphoryla-

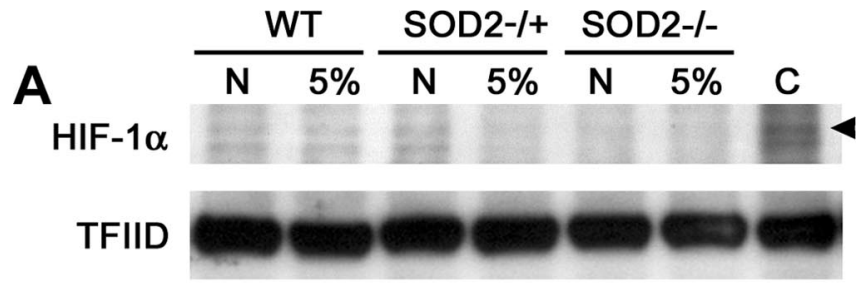

B
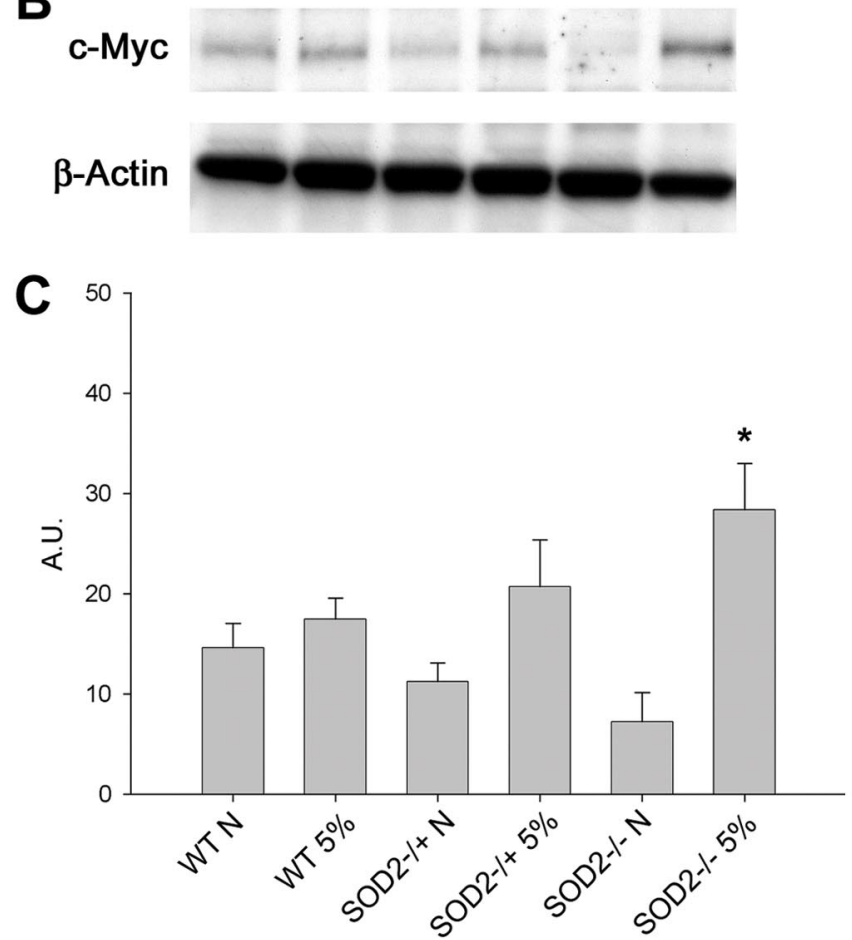

D

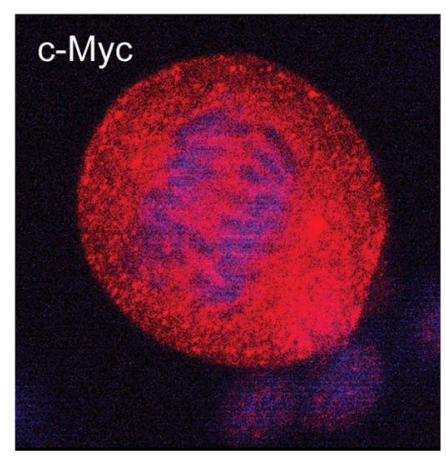

Figure 3. Induction of c-Mycin wild-type (WT), $\mathrm{SOD} 2-/+$, and SOD2 $-1-$ mice under normal conditions and $5 \% \mathrm{O}_{2}$ hypoxia. $\boldsymbol{A}$, Expression of HIF- $1 \alpha$ in wild-type, SOD2 $-1+$, and SOD2 - astrocytes under both $5 \% \mathrm{O}_{2}$ hypoxia $(5 \%)$ and normal conditions $(\mathrm{N})$, where a very low expression was seen. Astrocytes subjected to anoxia $\left(0 \% \mathrm{O}_{2}\right)$ were used as a positive control $(\mathrm{C})$, where a high level of HIF- $1 \alpha$ expression was observed. TFIID was used as an internal control. $\boldsymbol{B}$, Western blot analysis of c-Myc in wild-type, SOD2 - $/+$, and SOD2 - / - mouse astrocytes under normal conditions and 5\% $\mathrm{O}_{2}$ hypoxia. $\beta$-Actin was used as an internal control. $C$, Quantitative analysis of - -Myc showed upregulation in SOD2 $-1-$ astrocytes under $5 \% 0_{2}$ hypoxia ( ${ }^{*} p<0.05 ; n=3$ independent experiments). A.U., Arbitrary units. Error bars represent SEM. D, Immunostaining of c-Myc and DAPI in SOD2 - / astrocytes under $5 \% \mathrm{O}_{2}$ hypoxia using a laser confocal microscope. Increased activation of c-Myc was observed in the individual cell. Magnification is $1000 \times$.

tion was significantly upregulated with $5 \% \mathrm{O}_{2}$ hypoxia compared with normal culture conditions. p21 was undetectable in the wild-type astrocytes under both normal and $5 \% \mathrm{O}_{2}$ hypoxia conditions. The p21 protein level was much higher in the SOD2-/- 


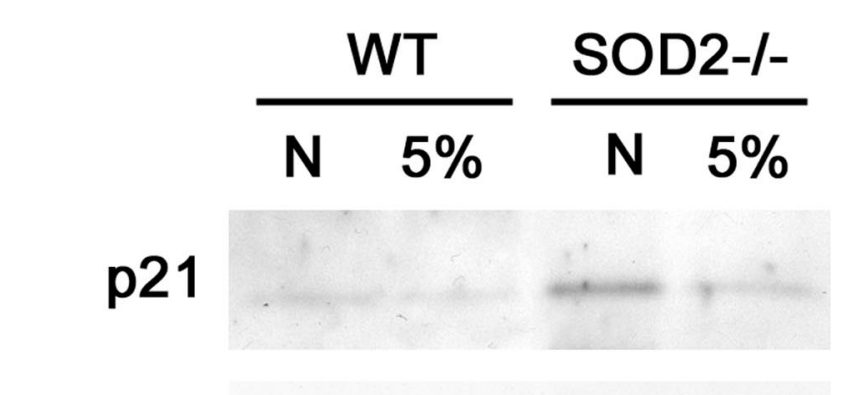

CDK4
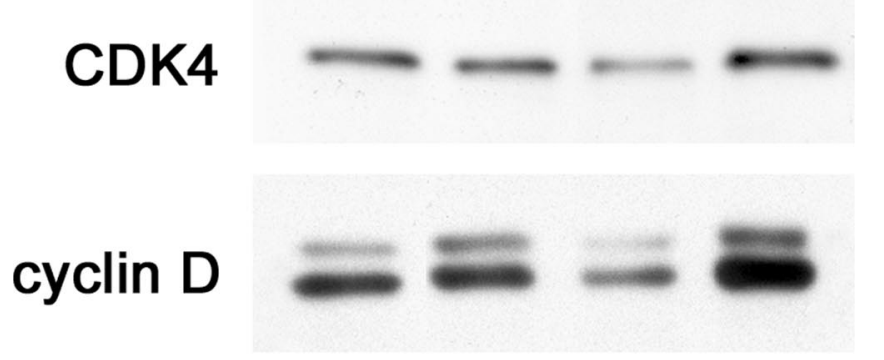

cyclin E

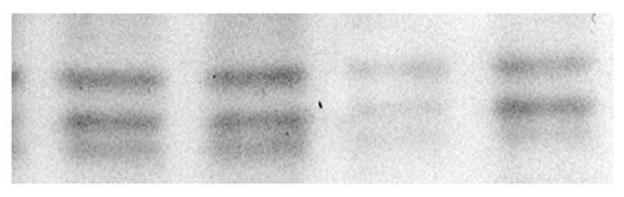

pCDK2
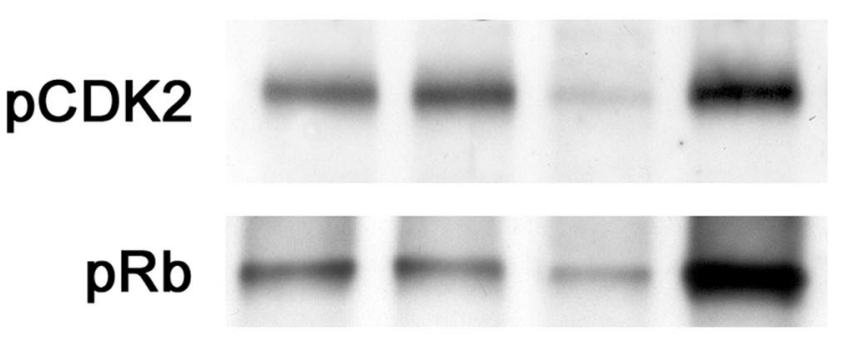

$\mathrm{pCdc} 2$

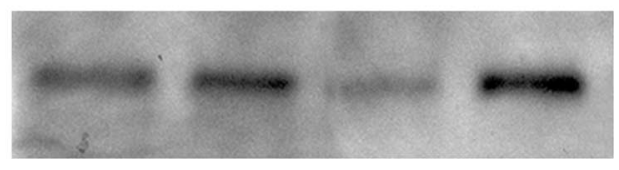

\section{$\beta$-Actin}

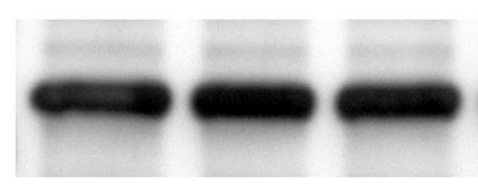

Figure 4. Induction of cell cycle control proteins under $5 \% \mathrm{O}_{2}$ hypoxia in wild-type (WT) and SOD2 - / - astrocytes. Western blot analysis of p21, CDK4, cyclin D, cyclin E, phosphorylated CDK2 (pCDK2), phosphorylated Rb (pRb) at Ser ${ }^{807 / 811}$, and phosphorylated $\mathrm{Cdc2}$ (pCdc2) in SOD2 $-1-$ astrocyte culture under normal conditions ( $\mathrm{N}$ ) and $5 \% \mathrm{O}_{2}$ hypoxia ( $5 \%$ ). There were no significant changes in the wild-type astrocytes, but in the SOD2 - $1-$ astrocytes they all increased except $\mathrm{p} 21$, which decreased ( $p<0.01 ; n=3-5$ independent experiments). $\beta$-Actin was used as an internal control.

astrocytes under normal conditions compared with the wild-type astrocytes. However, there was a significant decrease in the SOD2-/- astrocytes under $5 \% \mathrm{O}_{2}$ hypoxia (Fig. 4).

p53 activation in SOD2-/- astrocytes under 5\% $\mathrm{O}_{2}$ hypoxia There was no consistent activation of $\mathrm{p} 53$ in the wild-type astrocytes under $5 \% \mathrm{O}_{2}$ hypoxia compared with normal culture conditions, but both expression and activation of p53 increased significantly in the SOD2 $-1-$ astrocytes after $5 \% \mathrm{O}_{2}$ hypoxia. Expression of the downstream gene, p53-upregulated modulator of apoptosis (PUMA), however, was minimal in the SOD2-/-
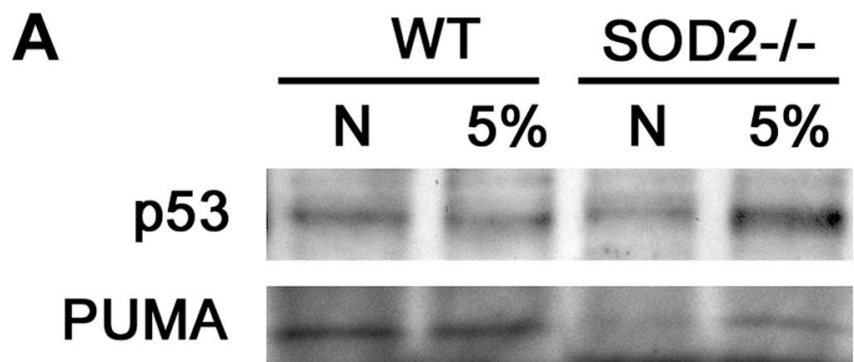

\section{$\beta$-Actin}

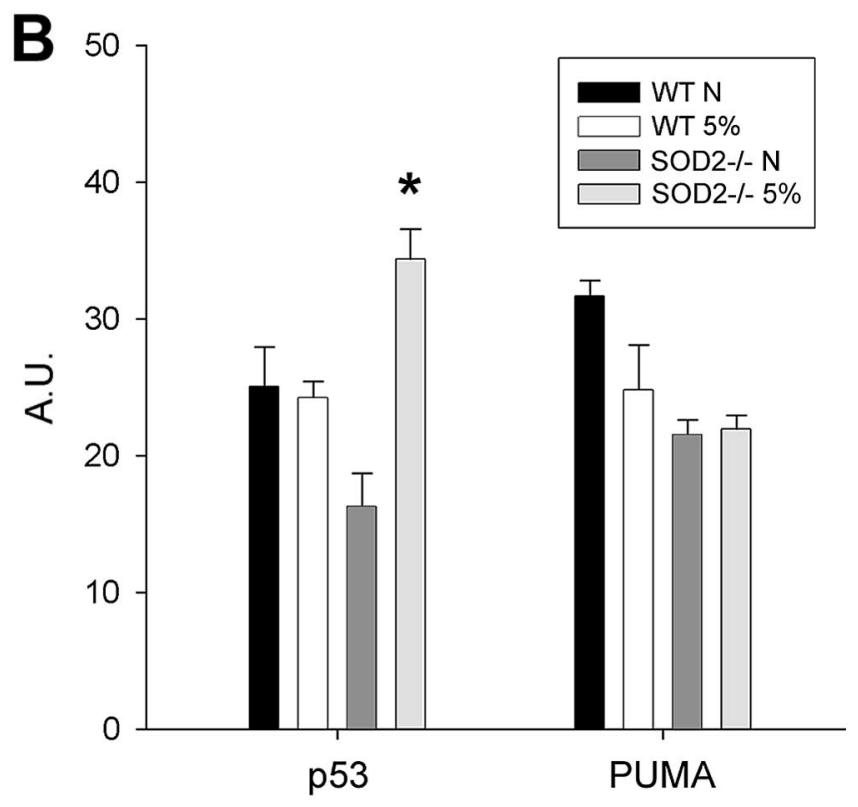

Figure 5. $\mathrm{P} 53$ and PUMA expression and activation in $\mathrm{SOD} 2-/-$ astrocytes under $5 \% \mathrm{O}_{2}$ hypoxia. $A$, Western blot analysis of $\mathrm{p} 53$ and the downstream target protein PUMA in the wild-type (WT) and SOD2 - / - mouse astrocytes under normal culture conditions (N) and $5 \% \mathrm{O}_{2}$ hypoxia (5\%). $\beta$-Actin was used as an internal control. $\boldsymbol{B}$, Quantitative analysis showed a significant increase in $\mathrm{p} 53$ under $5 \% \mathrm{O}_{2}$ hypoxia, whereas PUMA was induced to a much lower degree ${ }^{*} p<0.05 ; n=3$ independent experiments). A.U., Arbitrary units. Error bars represent SEM.

astrocytes under both normal and $5 \% \mathrm{O}_{2}$ hypoxia conditions (Fig. 5).

c-Myc plays a critical role in the survival of SOD2-I- astrocytes

To examine the effects of c-Myc on astrocyte survival and proliferation, c-Myc siRNA was used to knock down c-Myc expression. Fluorescent-labeled rhodamine-conjugated siRNA demonstrated transfection efficiency to be $\sim 80 \%$. A representative of the transfected astrocytes can be seen in Figure $6 \mathrm{~A}$. c-Myc protein expression decreased by $60 \%$ within 48 h of c-Myc siRNA administration as demonstrated by Western blot analysis and quantitation (Fig. 6B). Survival of the SOD2-/- astrocytes transfected by c-Myc siRNA decreased significantly to $60 \%$ under $5 \% \mathrm{O}_{2}$ hypoxia compared with the nontarget transfected SOD2 $-/-$ astrocytes (Fig. 6C). The wild-type astrocytes transfected by c-Myc siRNA showed no significant difference in survival (Fig. 6C).

Antisense c-Myc was also used to knock down c-Myc expres- 


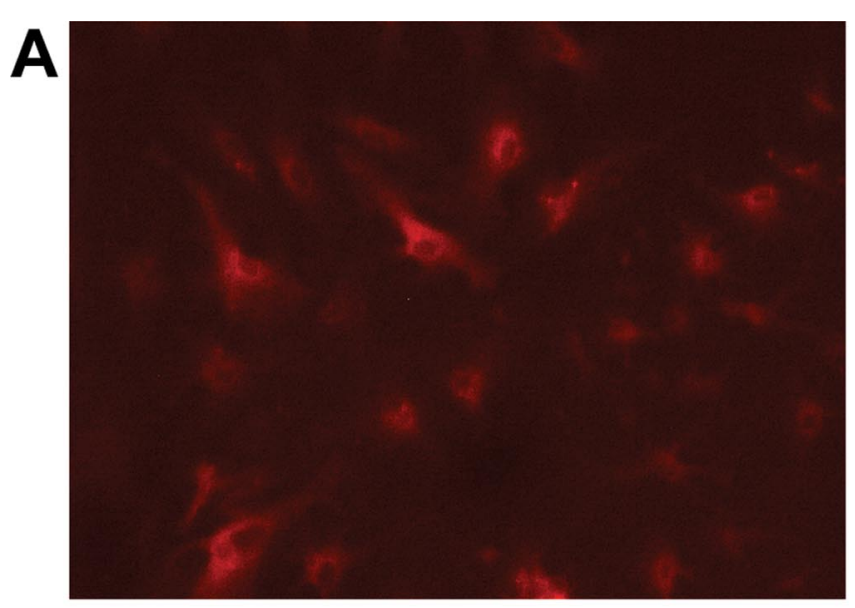

B

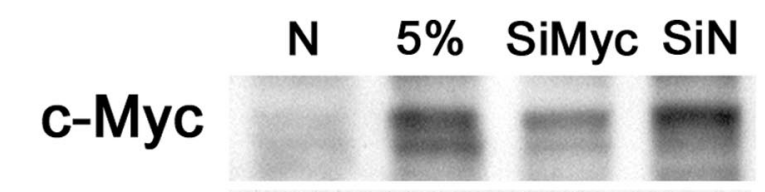

$\beta$-Actin

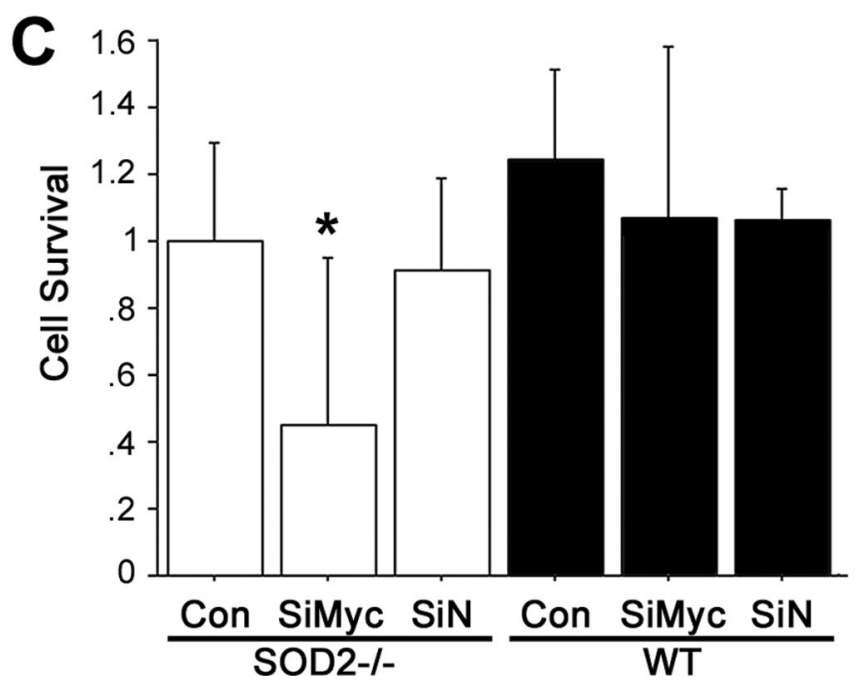

Figure 6. c-Myc played a critical role in the survival of SOD2 - / - astrocytes. $\boldsymbol{A}$, Fluorescent detection of c-Myc siRNA (SiMyc; rhodamine-conjugated) demonstrated $80 \%$ transfection efficiency in the SOD2 $-1-$ astrocytes. $\boldsymbol{B}$, Western blot analysis of cell cycle proteins in the SOD2 - $1-$ mouse astrocytes treated with SiMyc, under normal conditions (N) and $5 \% \mathrm{O}_{2}$ hypoxia (5\%). SiN, Cells transferred by nontarget siRNA. $\beta$-Actin was used as an internal control. SiMyc significantly reduced c-Myc expression by $60 \%$. C, Effect of SiMyc on cell viability as measured by ABTS in SOD2 - / - and wild-type (WT) mouse astrocytes under $5 \% \mathrm{O}_{2}$ hypoxia. SiN, ${ }^{*} p<0.05 ; n=3$. Con, Control. Error bars represent SEM.

sion. Treatment of SOD2-/- astrocytes with $100 \mathrm{~nm}$ of antisense c-Myc reduced both RNA and protein expression of c-Myc (Fig. $7 A$ ) and reduced the viability of SOD2-/- astrocytes by $\sim 25 \%$ (Fig. 7B). This confirms the results obtained from c-Myc siRNA transfection.

Moreover, expression of phosphorylated Rb, phosphorylated CDK2, Cdc2, cyclin D, cyclin E, and p53 decreased, whereas p21 expression increased in the transfected SOD2-/- astrocytes (Fig. 8A). Quantitative expression of the proteins is represented
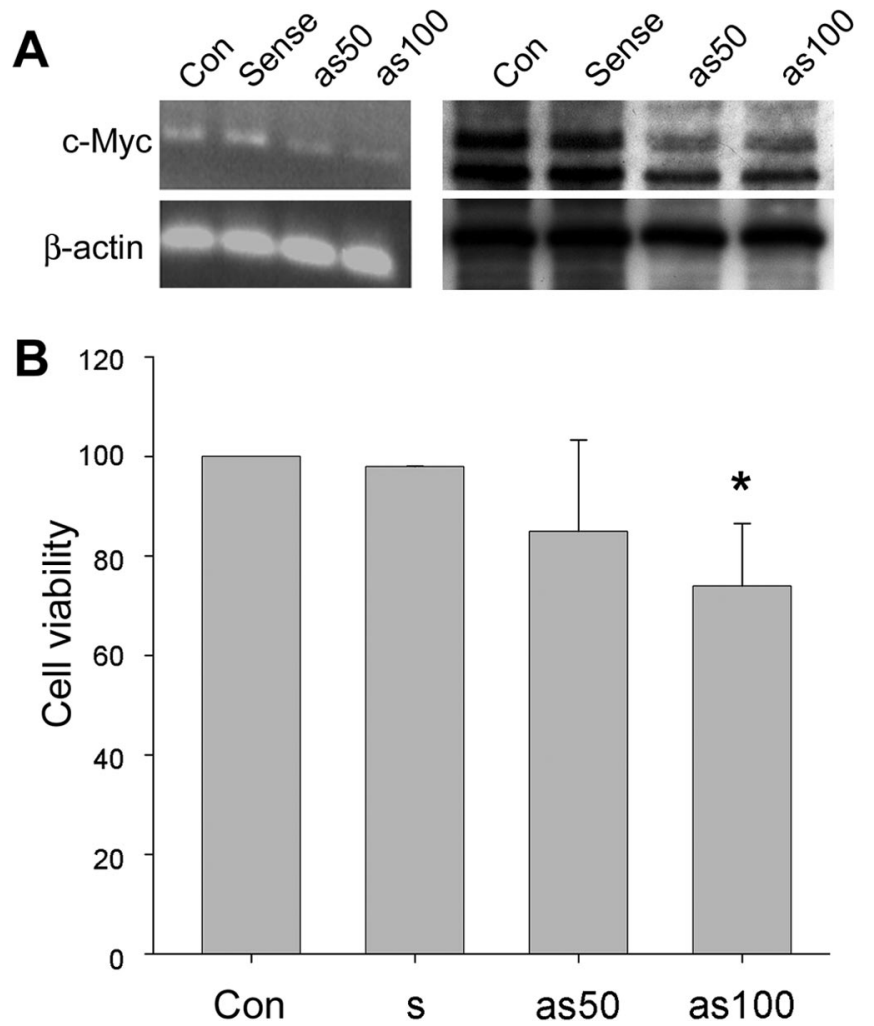

Figure 7. Knockdown of C-Myc by antisense decreases viability of SOD2 - / - astrocytes subjected to $5 \% \mathrm{O}_{2}$. A, RT-PCR with c-Myc primers shows decrease in c-Myc RNA in antisensetreated astrocytes. Western blot analysis also shows decrease in c-Myc protein expression in cells treated with antisense c-Myc at concentrations of $50 \mathrm{~nm}$ (as50) and $100 \mathrm{~nm}$ (as100). Con, Untreated SOD2 - I- astrocytes; Sense, SOD2 - / - astrocytes treated with sense oligomer of c-Myc. $B$, Effect of antisense c-Myc on cell survivability as measured by lactate dehydrogenase assay in SOD2 $-1-$ astrocytes treated with antisense c-Myc (as), sense c-Myc (s), and untreated astrocytes (Con) under $5 \% 0_{2}{ }^{*} p<0.05 ; n=3$.

in Figure $8 \mathrm{~B}$. Binding of CDK4 and cyclin D was also inhibited by the transfection of c-Myc SiRNA (Fig. 8C).

\section{Discussion}

Our study demonstrates that, under $5 \% \mathrm{O}_{2}$ hypoxia, c-Myc was upregulated in the SOD2-/- astrocytes. Without the induction of HIF- $1 \alpha$, c-Myc was dominant in the inhibition of $\mathrm{p} 21$ and the induction of proteins involved in the cell cycle process. Through direct or indirect stimulation of CDKs and cyclin, Rb is phosphorylated, and cells that would not otherwise grow pass through the $\mathrm{G}_{1} / \mathrm{S}$ checkpoint. Phosphorylated Cdc2, one of the Rb target genes, was also induced, causing cells to go through the $G_{2} / M$ phase. Our results suggest that this cascade of events plays a role in SOD $2-1-$ astrocyte proliferation under $5 \% \mathrm{O}_{2}$ hypoxia (supplemental Fig. 3, available at www.jneurosci.org as supplemental material).

HEt staining of SOD2 $-/-$ astrocytes under normal atmospheric $20 \% \mathrm{O}_{2}$ showed punctate staining, possibly representing mitochondrial localization, which was also observed by Sugawara et al. (2002). Thus, these SOD2-deficient astrocytes are susceptible to oxidative stress; however, when placed under $5 \% \mathrm{O}_{2}$ (mild hypoxia), they survived and proliferated (Fig. 1 and supplemental Fig. 2, available at www.jneurosci.org as supplemental material), suggesting the onset of an alternate trigger to compensate for the oxidative stress. In the present study, HIF- $1 \alpha$ did not appear to be upregulated and thus may not be involved in the survival of the SOD $2-/-$ astrocytes. HIF- $1 \alpha$ has been reported to be indirectly 


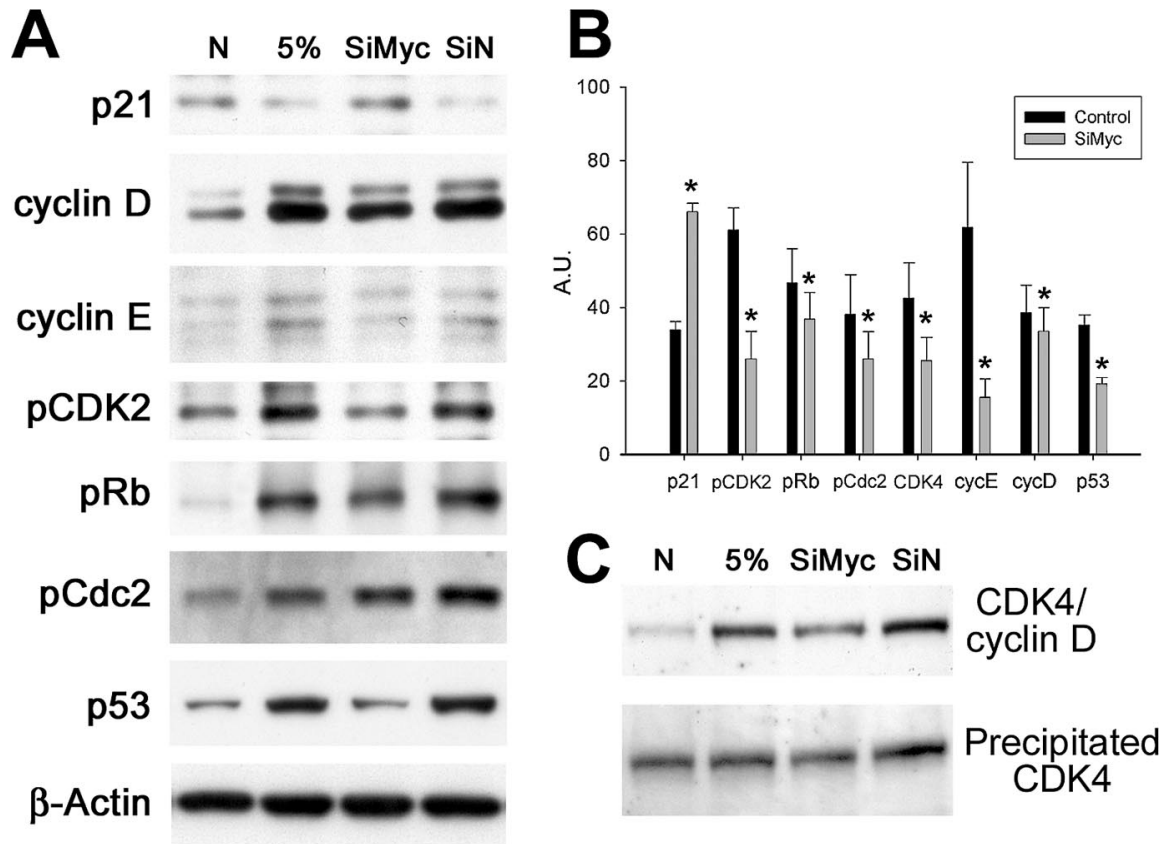

Figure 8. Expression of cell cycle proteins after knockdown of c-Myc by siRNA of c-Myc (SiMyc). $\boldsymbol{A}$, Western blot analysis of cell cycle proteins p21, cyclin D, cyclin E, phosphorylated CDK2 (pCDK2), pRb, and pCdc2, and p53 in SOD2 - / - astrocytes treated with SiMyc under normal $20 \% \mathrm{O}_{2}$ conditions (N) and $5 \% \mathrm{O}_{2}$ hypoxia (5\%). SiN indicates cells transferred by nontarget siRNA. $\boldsymbol{B}$, Quantitative analysis of the Western blots of the cell cycle proteins. C, CDK4 immunoprecipitates analyzed by Western blotting with a cyclin $D$ antibody in the astrocytes treated with SiMyc under normal conditions and $5 \% \mathrm{O}_{2}$ hypoxia. SiMyc significantly downregulated the binding of cyclin D and CDK4.

involved with p21 and c-Myc (Koshiji et al., 2004); however, in the present study, the upregulation of c-Myc suggests that it has a role in overcoming oxidative stress and assisting the SOD2-/astrocytes in survival and proliferation.

The results of our analysis of Bcl-2 expression were similar to those of a study that showed that complex 1-deficient cells that do not induce SOD2 did induce the Bcl-2 protein (Robinson, 1998). $\mathrm{Bcl}-2$ is known to protect against enhanced oxidative stress (Hochman et al., 1998; Papadopoulos et al., 1998; Xu et al., 1999). Overexpression of the $\mathrm{Bcl}-2$ or $\mathrm{Bcl}-\mathrm{X}_{\mathrm{L}}$ genes can protect against hydroxyl radical production by allowing cells to adapt to ROS overproduction (Esposti et al., 1999; Ouyang et al., 2002). In our experiments, there was an increased expression of Bcl-2 and $\mathrm{Bcl}-\mathrm{X}_{\mathrm{L}}$ in the SOD2-/- astrocytes under normal oxygen conditions, which protected the cells from ROS. However, under mild hypoxia, the expression of both proteins decreased, thus indicating that they are not critical factors in cell proliferation.

SOD2 activity in vivo is often downregulated in cancer cells compared with adjacent normal cells and the manganese SOD immunoreactive protein and its activity are barely detectable in contrast to other antioxidant enzymes (copper/zinc SOD, catalase, and glutathione peroxidase) (Oberley and Oberley, 1995). An inverse correlation between manganese SOD activity and cellular growth potential has been well documented in mitochondria of both cancer and nonmalignant cells (Oberley, 2001). This may explain the incapability of SOD2 $-/-$ cells to survive in atmospheric $20 \% \mathrm{O}_{2}$.

Previous reports showed that hypoxia promotes cell cycle arrest in diverse primary cell types (Âmellem et al., 1996). Genetic studies from mouse HIF- $1 \alpha$ null cells indicate that HIF- $1 \alpha$ is required for hypoxia-induced cell cycle arrest. Koshiji et al. (2004) showed that HIF-1 $\alpha$ upregulates p21, a key CDK inhibitor that controls the $G_{1}$ checkpoint. In their study, the PAS (Per-
ARNT-Sim) domain of a stable HIF- $1 \alpha$ mutant displaced c-Myc binding from the p21 promoter and functionally counteracted c-Myc repression of $\mathrm{p} 21$, even in the absence of a hypoxic signal. c-Myc has also been shown to inhibit Bcl-2 and Bcl- $\mathrm{X}_{\mathrm{L}}$ expression (Greider et al., 2002), supporting our observation of decreased expression of these proteins in the astrocytes under 5\% $\mathrm{O}_{2}$ hypoxia.

In our study, stable HIF- $1 \alpha$ protein expression was not detected under mild hypoxia $\left(5 \% \mathrm{O}_{2}\right)$, whereas c-Myc was strongly induced. In agreement with our findings, Jiang et al. (1996) reported that HIF- $1 \alpha$ is induced at much lower $\mathrm{O}_{2}$ tensions with half-maximal expression at $2 \%$ and maximal expression at $0.5 \%$. Moreover, c-Myc, is induced by ROS (Simon et al., 1998). In our study, we observed different levels of $\mathrm{c}-\mathrm{Myc}$ expression in all three groups of astrocytes (wild-type, SOD2-/+, and SOD2-/-). The results of c-Myc siRNA transfection and antisense $\mathrm{c}-\mathrm{Myc}$ treatment of SOD2-/- astrocytes suggest that $\mathrm{c}-\mathrm{Myc}$ is important for cell survival in the SOD2-/- astrocytes. Survivability decreased significantly, by $\sim 60 \%$, in c-Myc siRNA-transfected SOD2-/- astrocytes under $5 \% \mathrm{O}_{2}$ hypoxia, whereas the wildtype astrocytes transfected by c-Myc siRNA were not affected. Furthermore, in the transfected SOD2-/- astrocytes, expression of the downstream cell cycle proteins, Cdc2, cyclin D, cyclin E, and phosphorylated CDK2, decreased, whereas p21 increased. Binding of CDK4 and cyclin D was also inhibited. The schematic diagram in supplemental Figure 3 (available at www.jneurosci. org as supplemental material) suggests the pathway that SOD2 astrocytes might follow to proliferate with $5 \% \mathrm{O}_{2}$ hypoxia.

In other mammalian cells, as in PC-3 cells, SOD2 not only regulates cell survival by scavenging superoxide radicals but also affects cell proliferation by retarding the $\mathrm{G}_{1}$-to-S transition (Venkataraman et al., 2005). Because mitochondrial proteins are encoded in both mitochondria and the nuclear genome, biogenesis is a coordinated effort in which mitochondria transmit signals to the nucleus and vice versa (Felty and Roy, 2005). How mitochondria transmit these signals in the process of cell proliferation is still unknown. Recently, a model was proposed in which mitochondria are able to translate changes in mitochondrial ROS production into a signal that is relayed to the cytoplasm (Chen et al., 2004). This signal was shown to modulate nuclear factor- $\kappa \mathrm{B}$ mediation in tumor necrosis factor-induced apoptosis (Hughes et al., 2005). Transcription factors like nuclear factor- $\kappa$ B and others may then mediate expression of other genes such as c-fos, c-jun, and c-Myc (Kamata and Hirata, 1999). Most transcription factors are known to be redox-sensitive (Kamata and Hirata, 1999; Harris, 2002). In the SOD2-deficient astrocytes, c-Myc induction by this mechanism may be responsible for cell rescue.

$\mathrm{c}-\mathrm{Myc}$ is directly recruited to the p21 (Cip1) promoter by the DNA-binding protein Miz-1 (c-Myc-interacting zinc-finger protein) and inhibits p21 activity, allowing the cells to proceed to the $\mathrm{G}_{1} / \mathrm{S}$ phase. c-Myc also directly induces cyclin and CDKs, as shown in our study. Induction of $\mathrm{c}-\mathrm{Myc}$ is sufficient to drive quiescent cells into the cell cycle (Eilers et al., 1989). Overexpres- 
sion of c-Myc genes alone can also cause REF52 cells to divide (Smith et al., 1995). This deregulated c-Myc induction could make cells tolerant of the resulting genomic change (Smith et al., 1995), and this could explain SOD2 cell growth and proliferation through activation of cell cycle proteins, although this could also be detrimental to cancer cells. In our study, the expression of c-Myc and cell cycle proteins and the results of c-Myc transfection support the involvement of c-Myc induction in the survival and proliferation of the SOD2-/- astrocytes. With our experimental conditions, we also observed an elevated $\mathrm{p} 53$ level caused by c-Myc. p53 is a tumor suppressor protein and functions by inducing cell cycle arrest and apoptosis in response to DNA damage.

A growing number of $\mathrm{p} 53$ target genes has been implicated in mediating the apoptotic effects of $\mathrm{p} 53$. These include Bax, a proapoptotic Bcl-2 family member, and PUMA. The present study shows no significant induction of PUMA, a target gene of p53. There was no increase in Bad or Bax. PUMA deficiency blocks cell death throughout the developing nervous system after gammairradiation treatment, and endogenous wild-type p53 is not sufficient, in the absence of PUMA, for inducing efficient cell death (Jeffers et al., 2003). Hence, our present study indicates that the cells under $5 \% \mathrm{O}_{2}$ hypoxia were allowed to pass through the cell cycle checkpoint and that, in the absence of PUMA upregulation, the cells proliferated. In this study, p53 activation may serve as a warning signal of DNA damage that occurs as a result of cell proliferation. It appears that a threshold for the $\mathrm{p} 53$ protein level may exist, below which neither growth arrest nor cell death can occur; however, in our study, with the elevation of p53, the threshold was reached more quickly once DNA damage occurred.

The rapid disappearance of p21 after inhibition of transcription may contribute to p53 upregulation (Blagosklonny et al., 2002). SOD2 has also been suggested to have a reciprocal effect on p53 by downregulating its transcription (Drane et al., 2001). Despite the predominance of its proapoptotic effects during oxidative stress, p53 activation can activate other pathways and genes that may be involved in a compensatory mechanism to alleviate adverse effects of oxidative stress. Here, we report that the response of cell cycle proteins to SOD2-/ - astrocytes subjected to hypoxia was to rescue the cells and to allow them to proliferate. It is not clear, however, whether the same hypoxic conditions can rescue newborn SOD2 $-/-$ mice from death by activating the c-Myc signaling pathway. Nevertheless, our study presents a new molecular strategy that uses hypoxia to compensate for oxidative stress-induced mitochondrial dysfunction that occurs in many neurological disorders.

\section{References}

Åmellem Ø, Stokke T, Sandvik JA, Pettersen O (1996) The retinoblastoma gene product is reversibly dephosphorylated and bound in the nucleus in $S$ and $\mathrm{G}_{2}$ phases during hypoxic stress. Exp Cell Res 227:106-115.

Bindokas VP, Jordán J, Lee CC, Miller RJ (1996) Superoxide production in rat hippocampal neurons: selective imaging with hydroethidine. J Neurosci $16: 1324-1336$

Blagosklonny MV, Demidenko ZN, Fojo T (2002) Inhibition of transcription results in accumulation of Wt p53 followed by delayed outburst of p53-inducible proteins: p53 as a sensor of transcriptional integrity. Cell Cycle 1:67-74.

Brooke SM, Bliss TM, Franklin LR, Sapolsky RM (1999) Quantification of neuron survival in monolayer cultures using an enzyme-linked immunosorbent assay approach, rather than by cell counting. Neurosci Lett 267:21-24.

Carmeliet P, Dor Y, Herbert J-M, Fukumura D, Brusselmans K, Dewerchin M, Neeman M, Bono F, Abramovitch R, Maxwell P, Koch CJ, Ratcliffe P,
Moons L, Jain RK, Collen D, Keshet E (1998) Role of HIF-1 $\alpha$ in hypoxia-mediated apoptosis, cell proliferation and tumour angiogenesis. Nature 394:485-490.

Chan PH (1996) Role of oxidants in ischemic brain damage. Stroke $27: 1124-1129$.

Chan PH (2005) Mitochondrial dysfunction and oxidative stress as determinants of cell death/survival in stroke. Ann NY Acad Sci 1042:203-209.

Chan PH, Chen SF, Yu ACH (1988) Induction of intracellular superoxide radical formation by arachidonic acid and by polyunsaturated fatty acids in primary astrocytic cultures. J Neurochem 50:1185-1193.

Chen K, Thomas SR, Albano A, Murphy MP, Keaney Jr JF (2004) Mitochondrial function is required for hydrogen peroxide-induced growth factor receptor transactivation and downstream signaling. J Biol Chem 279:35079-35086.

Copin J-C, Gasche Y, Li Y, Chan PH (2001) Prolonged hypoxia during cell development protects mature manganese superoxide dismutase-deficient astrocytes from damage by oxidative stress. FASEB J 15:525-534.

Devi GR, Beer TM, Corless CL, Arora V, Weller DL, Iversen PL (2005) In vivo bioavailability and pharmacokinetics of a $c$-MYC antisense phosphorodiamidate morpholino oligomer, AVI-4126, in solid tumors. Clin Cancer Res 11:3930-3938.

Drane P, Bravard A, Bouvard V, May E (2001) Reciprocal down-regulation of $p 53$ and SOD2 gene expression-implication in p53 mediated apoptosis. Oncogene 20:430-439.

Eilers M, Picard D, Yamamoto KR, Bishop JM (1989) Chimaeras of Myc oncoprotein and steroid receptors cause hormone-dependent transformation of cells. Nature 340:66-68.

Esposti MD, Hatzinisiriou I, McLennan H, Ralph S (1999) Bcl-2 and mitochondrial oxygen radicals. J Biol Chem 274:29831-29837.

Felty Q, Roy D (2005) Mitochondrial signals to nucleus regulate estrogeninduced cell growth. Med Hypotheses 64:133-141.

Forte A, Galderisi U, De Feo M, Gomez MF, Esposito S, Sante P, Renzulli A, Agozzino L, Hellstrand P, Berrino L, Cipollaro M, Cotrufo M, Rossi F, Cascino A (2005) c-Myc antisense oligonucleotides preserve smooth muscle differentiation and reduce negative remodelling following rat carotid arteriotomy. J Vasc Res 42:214-225.

Gardner LB, Li Q, Park MS, Flanagan WM, Semenza GL, Dang CV (2001) Hypoxia inhibits $G_{1} / S$ transition through regulation of $p 27$ expression. J Biol Chem 276:7919-7926.

Graeber TG, Osmanian C, Jacks T, Housman DE, Koch CJ, Lowe SW, Giaccia AJ (1996) Hypoxia-mediated selection of cells with diminished apoptotic potential in solid tumours. Nature 379:88-91.

Greider C, Chattopadhyay A, Parkhurst C, Yang E (2002) BCL-xL and BCL-2 delay Myc-induced cell cycle entry through elevation of p27 and inhibition of G1 cyclin-dependent kinases. Oncogene 21:7765-7775.

Harris AL (2002) Hypoxia-a key regulatory factor in tumour growth. Nat Rev Cancer 2:38-47.

Hochman A, Sternin H, Gorodin S, Korsmeyer S, Ziv I (1998) Enhanced oxidative stress and altered antioxidants in brains of $B c l$-2-deficient mice. J Neurochem 71:741-748.

Hughes G, Murphy MP, Ledgerwood EC (2005) Mitochondrial reactive oxygen species regulate the temporal activation of nuclear factor $\kappa \mathrm{B}$ to modulate tumour necrosis factor-induced apoptosis: evidence from mitochondria-targeted antioxidants. Biochem J 389:83-89.

Jeffers JR, Parganas E, Lee Y, Yang C, Wang J, Brennan J, MacLean KH, Han J, Chittenden T, Ihle JN, McKinnon PJ, Cleveland JL, Zambetti GP (2003) Puma is an essential mediator of p53-dependent and -independent apoptotic pathways. Cancer Cell 4:321-328.

Jiang B-H, Semenza GL, Bauer C, Marti HH (1996) Hypoxia-inducible factor 1 levels vary exponentially over a physiologically relevant range of $\mathrm{O}_{2}$ tension. Am J Physiol 271:C1172-C1180.

Kamata H, Hirata H (1999) Redox regulation of cellular signalling. Cell Signal 11:1-14.

Koshiji M, Kageyama Y, Pete EA, Horikawa I, Barrett JC, Huang LE (2004) HIF- $1 \alpha$ induces cell cycle arrest by functionally counteracting Myc. EMBO J 23:1949-1956.

Li Y, Huang T-T, Carlson EJ, Melov S, Ursell PC, Olson JL, Noble LJ, Yoshimura MP, Berger C, Chan PH, Wallace DC, Epstein CJ (1995) Dilated cardiomyopathy and neonatal lethality in mutant mice lacking manganese superoxide dismutase. Nat Genet 11:376-381.

Liu J, Narasimhan P, Yu F, Chan PH (2005) Neuroprotection by hypoxic 
preconditioning involves oxidative stress-mediated expression of hypoxia-inducible factor and erythropoietin. Stroke 36:1264-1269.

Liu Z-J, Ueda T, Miyazaki T, Tanaka N, Mine S, Tanaka Y, Taniguchi T, Yamamura H, Minami Y (1998) A critical role for cyclin C in promotion of the hematopoietic cell cycle by cooperation with c-Myc. Mol Cell Biol 18:3445-3454.

Oberley LW (2001) Anticancer therapy by overexpression of superoxide dismutase. Antioxid Redox Signal 3:461-472.

Oberley LW, Oberley TD (1995) Reactive oxygen species in the aetiology of cancer. In: Drugs, diet, and disease, Vol 1 (Ioannides C, Lewis DFV, eds), pp 47-63. New York: Ellis Horwood.

Ouyang Y-B, Carriedo SG, Giffard RG (2002) Effect of Bcl- $\mathrm{X}_{\mathrm{L}}$ overexpression on reactive oxygen species, intracellular calcium, and mitochondrial membrane potential following injury in astrocytes. Free Radic Biol Med 33:544-551.

Papadopoulos MC, Koumenis IL, Xu L, Giffard RG (1998) Potentiation of murine astrocyte antioxidant defence by bcl-2: protection in part reflects elevated glutathione levels. Eur J Neurosci 10:1252-1260.

Robinson BH (1998) The role of manganese superoxide dismutase in health and disease. J Inherit Metab Dis 21:598-603.

Saito A, Narasimhan P, Hayashi T, Okuno S, Ferrand-Drake M, Chan PH (2004) Neuroprotective role of a proline-rich Akt substrate in apoptotic neuronal cell death after stroke: relationships with nerve growth factor. J Neurosci 24:1584-1593.
Semenza GL (1999) Perspectives on oxygen sensing. Cell 98:281-284.

Shimizu S, Eguchi Y, Kosaka H, Kamiike W, Matsuda H, Tsujimoto Y (1995) Prevention of hypoxia-induced cell death by Bcl-2 and Bcl-xL. Nature 374:811-813.

Simon AR, Rai U, Fanburg BL, Cochran BH (1998) Activation of the JAK-STAT pathway by reactive oxygen species. Am J Physiol 275:C1640-C1652.

Smith KA, Agarwal ML, Chernov MV, Chernova OB, Deguchi Y, Ishizaka Y, Patterson TE, Poupon M-F, Stark GR (1995) Regulation and mechanisms of gene amplification. Philos Trans R Soc Lond B Biol Sci 347:49-56.

Sugawara T, Noshita N, Lewén A, Gasche Y, Ferrand-Drake M, Fujimura M, Morita-Fujimura Y, Chan PH (2002) Overexpression of copper/zinc superoxide dismutase in transgenic rats protects vulnerable neurons against ischemic damage by blocking the mitochondrial pathway of caspase activation. J Neurosci 22:209-217.

Venkataraman S, Jiang X, Weydert C, Zhang Y, Zhang HJ, Goswami PC, Ritchie JM, Oberley LW, Buettner GR (2005) Manganese superoxide dismutase overexpression inhibits the growth of androgen-independent prostate cancer cells. Oncogene 24:77-89.

Xu L, Lee JE, Giffard RG (1999) Overexpression of bcl-2, bcl- $\mathrm{x}_{\mathrm{L}}$ or hsp70 in murine cortical astrocytes reduces injury of co-cultured neurons. Neurosci Lett 277:193-197. 